\title{
Poster Exhibition Based Learning on Human Reproduction Concept
}

\author{
Kaspul \\ Department of Biology Education, Faculty of Teacher Training and Education \\ Universitas Lambung Mangkurat \\ Banjarmasin, Indonesia \\ kspdarmawi@yahoo.co.id
}

\begin{abstract}
Students' understanding on human reproduction concept at Pharmacy Major of ISFI Vocational Middle School Banjarmasin was low because of too many words and scientific terms in Greek. In addition, the process was too complicated and abstract. Based on this condition, it was necessary to implement an appealing model of learning which helps students to master the learning materials. One of the strategies is poster exhibition based learning. The aim of this research was to assess learning quality, students' motivation and implementation of poster exhibition based learning on human reproduction concept at Pharmacy Department of ISFI Vocational Middle School in Banjarmasin. This research was a quasi-experimental design which compared poster exhibition based learning and conventional learning on human reproduction concept. The treefold results showed that poster exhibition based learning on human reproduction concept was effective for learning quality, the students had high motivation, and the result on the assessment of classical learning mastery was high.
\end{abstract}

Keywords-Human Reproduction Concept, Learning, Poster Exhibition

\section{INTRODUCTION}

Science and technology are developing rapidly. The mastery of science and technology can be obtained through a learning process in formal educational institution. School as formal educational institution performs educational activities and transfer of science and technology. Unfortunately, educational process and transfer of science and technology are sometimes not smooth. These matters are also difficult to be absorbed and mastered by students. Thus, a method of learning that enables students to master learning materials is needed.

Pharmacy Major of Vocational Secondary School prepares students to become an assistant pharmacist engaged in community service in the field of health, in particular the pharmaceutical field. Biology is one of the subjects taught in Pharmacy Major of Vocational Secondary School. Like other educational institutions that have Biology, learners seems to have difficulties in mastering the study material. The reasons are most likely because there are too much rote and too many scientific terms in Greek and the process is too complicated and abstract. Thus, in addition to memorization, students also need a good understanding in Biology. This students' difficulty appears to be more apparent when it comes to the concept of human. The concept of human reproduction at Pharmacy Major of Vocational Secondary School is taught at the third grade on sixth semester. The concept of human reproduction includes sub-concept of human reproductive organs; sex cells; fertilization; division phase; blastula, gastrula, morula, organogenesis; embryonic membranes and twins [1].

Based on the background, an attractive learning model is needed to enable students to master the learning material. Efforts should be made to optimize the student's mastery on human reproductive material by learning with the implementation of poster exhibition based learning on human reproduction concept. A learning model in general is characterized by the task structure, the structure of interest and reward structures. Task structure refers to the way learning is organized and the type of student activities. The structure of interest is the amount of interdependence on task, while the reward structure is a student satisfaction in achieving learning outcomes (mastering learning materials) at the completion of learning [2].

Biology learning based on poster exhibition is a method of learning in which students can share their experience about biology projects either in individuals, groups or the whole class with other students in their school. The poster exhibition based learning on the concept of the human reproduction is a learning that presents the atmosphere of the poster exhibition. This learning environment can increase the activity of students in learning. The increased activity of students in the learning process will improve the quality of learning and learning outcomes [3]. The poster exhibition based learning project is a combination of various models, learning strategies and learning methods as portfolio learning model [4], cooperative learning model [2], discussions method, group work, and simulations [5][6]. The learning approach used is also a combination of various approaches such as systems approach [7], process skills approach, active student approach, and mastery learning approach [8]. Poster mentioned in this research is charts made on standard size poster board in the form of images, graphs, charts or maps concepts.

The objective of this research was to assess learning quality, students' motivation and assessment of learning 
implementation based on poster exhibition project on human reproduction concept at Pharmacy Major of ISFI Vocational Secondary School in Banjarmasin.

\section{METHOD}

This research was a quasi-experimental design which compared poster exhibition based learning and conventional learning on human reproduction concept. The instruments used in this research were the observation sheet for the learning, student questionnaire and an evaluation sheet for learning outcomes.

The population of the research was third grade students on Pharmacy Major of ISFI Vocational Secondary School in Banjarmasin. The total samples were divided into two classes with students' similar abilities from each class. Both classes were treated with different treatment. Class III A, consisting of 44 students, was treated with conventional learning dominated by lectures as a control class, while Class III B consisting 43 students was treated with poster exhibition based learning. Both classes learned the same human reproduction material.

The research was conducted with the following steps: (1). Conventional learning was implemented in Class III A and was dominated by lectures. (2) Poster exhibition based learning was implemented in Class III B. Learning steps were carried out as follows: (a) Students were divided into 10 groups and each group consisted of 4-5 students; (b) Each group was given the task at home for 10 days to examine the different sub concepts on the concept of Human Reproduction. The results of the study were outlined in the form of a poster (pictures, graphs, charts or maps concept); (c) Observation of the learning process was carried out by other teachers in both classes. The observer then filled the observation sheet. (3) After the learning process ended, a post-test was conducted for both classes. The post-test was conducted to determine student learning mastery. Individual's learning mastery is achieved if the students passed the $65 \%$ of post-test score, whereas accumulative learning mastery is achieved when at least $85 \%$ of students in class passed the $65 \%$ of post-test score.

The results were analyzed by means of: (1) The quality of learning was analyzed based on observation sheets filled out by observer. (2) Student motivation was analyzed based on the questionnaire filled by the students. (3) Student learning outcomes were analyzed based learning mastery both individual and accumulative. Individual learning mastery can be achieved if the students can master the learning material at least $65 \%$. Whereas the accumulative mastery learning can be achieved if at least $85 \%$ of students can master the learning material at least with $65 \%$ achievement.

\section{RESULT AND DISCUSSION}

Before Student motivation in the implementation of poster exhibition based learning on the human reproduction concept at Pharmacy Major of ISFI Vocational Secondary School Banjarmasin was shown from intensive activities of students in learning participation. Four students managed to get very good with A score in motivation, participation, creativity and skills of students. Although the students' attention could not obtain A score, the quality was quite good with B score. Teacher activities had very good quality with A score in the use of learning strategies; communication and interaction with students; mastery of the learning concept, and encouragement of students' activity. Teacher activities had good quality with the B score in learning management; learning resources and time; demonstration of the teaching method; the relevance of concepts and learning materials.

The result of conventional learning showed a lower quality of student activity with the score of E, creativity and skills of students with the score of $\mathrm{D}$, students' participation with the score of $\mathrm{C}$. The teacher activity showed a lower score with the score of E, use of learning strategies with the score of D, communication and interaction with students, demonstration of the teaching method with the score of $\mathrm{C}$, the relevance of concepts and learning materials with the score of $\mathrm{B}$.

Student learning outcomes in the learning implementation based on poster exhibition achieved an average score of $97.67 \%$ and accumulative mastery achieved score of $86.46 \%$. Moreover, student learning outcomes in conventional learning showed a lower learning outcomes with an average of 70.002 and a level of accumulative mastery achieved score of $79.55 \%$.

Problems in the implementation learning based on poster exhibition that students need a long time to prepare posters, but the problems did not interfere learning process because of the time allocation for implementing poster exhibition based learning outside of regular school hours. In addition, students need to have a lot of skills such as the ability to read, understand, summarize, draw/paint and explain. Teachers' problems in the implementation of poster exhibition basedlearning were necessary preparation as well as intensive and comprehensive monitoring. The problems of students in conventional learning were elusive and less attractive learning concept, while the problems of teacher were difficulties in encouraging the students.

The increase of students' activity in poster exhibition based learning is caused by how much students' participation involved in this learning method, starting from planning, preparing, executing and evaluating. Poster exhibition based learning challenges the students to develop their creativity. Students become motivated, involved and open minded when they have only a little problem regarding their learning [9]. Aside from that, the sympathy and understanding of students have a good influence to their learning process [10]. While in conventional method, students tend to only wait for and accept what the teachers explained and in turn cause them to be more passive with low to almost none motivation and attention. There is even chance that if the topic of learning material is not about human's reproduction, the motivation of the student might be worse. Conventional method of learning is dominated by lectures. Consequently, the students cannot develop their 
creativity. There is no room to increase their own creativity in conventional learning method.

The problem in poster exhibition based learning is the time needed for the preparation. However, with extra time given for the preparation, teachers can get a better focus on the learning and feel an exciting challenge in the learning [11]. Learning needs more time and more skill like reading, understanding, citing, painting and giving a presentation. Lot of skills and expertise are needed by the students in poster exhibition based learning since this learning model indirectly teaches students to learn skill that they have not mastered yet. The students can also learn from their peers who have mastered the skills. This shows that there is a good teamwork and organization among the students. Interaction among groups also occur when it comes to presentation on the exhibition so that everyone will try their best to master their exhibition's topics. Other groups will try to understand and get the knowledge from the exhibition they visit. The only obstacle in conventional learning is that the teacher needs preparation to do the lecture with students' focus on the learning as the aim. In this way, it is even still difficult for the teachers to keep the students as active as possible. The use of learning sources needs teacher's competency to guide students so that they get enough materials [12].

Teachers' activity in poster exhibition based learning has a good quality with A score on strategy component, communication and interaction with students, mastery of the topics and how the teacher makes the students more active. B score was obtained on routine assignment component, facility and time, and teaching method demonstration. This good quality of teacher's activity can happen if the planning is executed well. Besides, art expertise, intuition, perspective emotional reflection and intellectuality can help the teachers in using learning methods [13]. The variation in the learning context could also help the learning process [11]. In conventional learning method with same materials in the other class, lower quality of teacher activity was found . It seems that class with conventional learning method shows that the teacher as the center of learning could not develop the students' learning process.

Poster exhibition based learning has a better learning quality as Roestiyah said that a good learning process focuses on the main concept and principle [5]. Besides, discipline of science is involved, students' skills are developed through assignment, and students are given chance so that they could learn by themselves and construct their own knowledge. This is supported by [14] who says that to learn something, listening, seeing and asking about it are necessary.
Poster exhibition based learning showed a better result compared to the conventional method. This shows that a better learning process is also followed by a better learning outcome. In a suitable condition, every student is able to learn well and get a better result [15]. It means that anyone who studies well will also get a good learning and enough time [8].

\section{CONCLUSION}

Based on this research and discussion, it can be concluded that learning based on poster exhibition with human reproduction as its topic on Pharmacy Major of ISFI Vocational Secondary School in Banjarmasin shows a good learning quality and high learning motivation. The accumulative learning mastery reaches $97.67 \%$ with a high average score of 86.48 .

\section{REFERENCES}

[1] Anonim, 2006, Garis-garis Besar Program Pengajaran Biologi untuk Sekolah Menengah Farmasi. Jakarta: Pusdiknas, 2006.

[2] Muslimin Ibrahim, Pembelajaran Kooperatif, Surabaya: Universitas Negeri Surabaya Press, 2010.

[3] Suyadi, Pelibatan Siswa dalam Pembuatan Model Pencernaan sebagai Strategi Peningkatan Aktivitas Belajar Siswa. Pelangi Pendidikan, 2012.

[4] Dasim Budimansyah, Model Pembelajaran Berbasis Portofolio, Bandung: Genesendo, 2013.

[5] Roestiyah, Strategi Mengajar, Program Pengajaran. Jakarta: Rineka Cipta, 2011.

[6] Oemar Hamalik, Strategi Belajar Mengajar. Bandung: Mandar Maju, 2013.

[7] A. Tresna Sastrawijaya, Pengembangan Program Pengajaran. Jakarta: Rineka Cipta, 2011.

[8] Moh. Uzer Usman \& Lilis Setiawati, Upaya Optimalisasi Kegiatan Belajar Mengajar. Bandung: Remaja Rosda Karya, 2011.

[9] Paul Ginnis, Trik \& Taktik Mengajar, Strategi Meningkatkan Pencapaian Pengajaran di Kelas. Jakarta: Indeks, 2008.

[10] Bpbby De Porter, Mark Reardon, and Sarah Singer-Nouri, Quantum Teaching, Mempraktikkan Quantum Learning di Ruang-ruang Kelas. Bandung: Kaifa, 2015.

[11] LouAnne Johnson, Pengajaran yang Kreatif dan Menarik, Cara Membangkitkan Minat Siswa Melalui Pemikiran. Jakarta: Indeks, 2008.

[12] Gene F. Hall, Linda F. Quinn, \& Donna M. Gollnick, Mengajar dengan Senang, Menciptakan Perbedaan dalam Pembelajaran. Jakarta: Indeks, 2008.

[13] Dave Meier, The Accelerated Learning Handbook: Panduan Kreatif dan Efektif Merancang Program Pendidikan dan Pelatihan. Bandung: Kaifa, 2015.

[14] Mel. Silberman, Cara Pelatihan dan Pembelajaran Aktif. Jakarta: Indeks, 2010.

[15] Kunandar, Guru Profesional, Implementasi Kurikulum Tingkat Satuan Pendidikan (KTSP) dan Sukses dalam Sertifikasi Guru. Jakarta: Rajawali Press, 2008. 